\title{
Colleges for Women’s Torah Study (Midrashoth) as Change Agents in Women's Role Within Religious Zionism in the Past and Present in the Postmodern Era
}

\author{
Nitza Davidovitch, Elisheva Munk, Hadar Baruch \\ Ariel University, Ariel, Israel
}

Torah study by women has been a point of dissension over the years. Side by side with partial support, the subject has aroused resistance within the religious community. In recent years, Torah-oriented study settings for women have greatly expanded, concurrent with the rise in the value of Torah study as part of religious women's life. One option that has become more available for women in religious Zionist society in recent years, as part of the moratorium, is colleges for Torah study by women, called "Midrashoth" (single: Midrasha). The purpose of the current study was to examine whether and to what degree full-program Midrashoth constitute change agents for their students by shaping the image of women within religious Zionist society. The first Torah-oriented Midrashoth were opened in the 1990s, with one main aim to enable women to study Torah and Talmud and thus attempt to reach an equal level as men in this area. Previously, the study of "Torah Lishmah" (i.e., Torah for its own sake) was less customary and not perceived as part of the role of women in religious Zionist society. Since the opening of the Midrashoth and until the present, several interesting developments have occurred. The first was the significant increase in Torah-oriented Midrashoth for women, particularly full-program Midrashoth. At present, there are 25 full-program Midrashoth. Another development is the timing of studies at the Midrasha. In the past, some women would study at Midrashoth after completing their national service, particularly when a full program was involved. But at present, there is an increase in full-program Midrashoth even before national service. The current study found that nearly half the respondents had studied a full program before their national service. Another interesting change that is occurring in recent years involves women's motives for studying at the Midrashoth. As stated, the main purpose for which Torah-oriented Midrashoth were established was for women's Torah study. This purpose has remained valid, but it has been joined by other more conspicuous motives related to constructing one's personal identity and self-focus. This study hypothesized that an association would be found between the growth process of Torah-oriented Midrashoth and the enhanced status of women in religious Zionist society. Moreover, it was hypothesized that an association would be found between the motives of students to study in the Midrashoth and current-day postmodern processes. Torah-oriented Midrashoth were found to have an important role in enhancing the status of women in religious Zionist society, by means of a comparison between the results of a previous survey on women's status and the current results. In most aspects, an increase was found in the present compared to the past. Women now perceive Torah studies for women more positively, with a rise of more than $30 \%$ in answer to the

Nitza Davidovitch, Prof. head of Teacher Training Program, Education Department, Ariel University, Ariel, Israel.

Elisheva Munk, Education Department, Ariel University, Ariel, Israel.

Hadar Baruch, Education Department, Ariel University, Ariel, Israel. 
question to what degree Midrashoth have a very positive impact on the life of religious women today, and these seem to serve as change agents for enhancing women's status in religious Zionist society. In addition, it appears that the postmodern approach is currently manifested in respondents' motivation to study in the Midrashoth. The main reasons seem to be the desire to shape one's personal and religious world view and, in general, an increased focus on oneself and less on Torah study or attempts to resemble men’s Torah study.

Keywords: women, religious, Torah study, Midrashoth

\section{Introduction}

In recent years, Torah-oriented colleges for women (called "Midrashoth”, single "Madrasah") have expanded considerably, concurrent with the rising value of Torah study among religious women. One option that has become increasingly available for women in religious Zionist society in recent years, as part of the moratorium, is these colleges for Torah study by women. At present, there are 30 full-program Midrashoth and some 1,000 women study in these settings (Ereli, 2018). The purpose of the current study is to examine whether and to what degree full-program Midrashoth constitute change agents for respondents by shaping the image of women in religious Zionist society.

Also, it will examine the personal, familial, and academic background characteristics of students at the Midrashoth; the motives drive their decision to study there, the current nature of these studies, and who can afford to take a moratorium. In addition, there are the motives for deciding to study at a Madrasah compatible with postmodern processes that religious women are undergoing.

\section{Midrashoth for Torah Study by Women}

Torah-oriented Midrashoth for women are colleges for Torah study by women in a variety of settings: "Torah Lishmah" studies in a full intensive setting, Torah study concurrent with academic studies, Torah-oriented studies concurrent with national or military service, partial programs for Torah-oriented studies, training programs for religious roles in the community, and continued learning programs for graduates of Torah-oriented studies. The current study shall focus on the full-program setting, the "classic" program where "Torah Lishmah" is studied in a full and intensive setting. This setting is usually attended by women after completing their national/military service as well as immediately after high school. This is usually a full-year residential program that runs for at least five days a week. Aside from theoretical studies, social activities, such as joint weekends are also held at the Midrashoth, in addition to trips and tours, as well as community work within the close environment (Lotan \& Schwartz, 2006).

"Torah Lishmah" studies for women began to evolve at Midrashoth in Israel in the 1970s (Lotan \& Schwartz, 2006), and in the two recent decades, Torah-oriented Midrashoth, as well as high school level Ulpanot (schools of Torah study for religious girls), have undergone considerable development. There are now over 50 different Midrashoth (Ne'emanei Torah Va'Avodah, 2018). According to data of the Forum of Torah-Oriented Midrashoth for Girls, which is an umbrella organization encompassing the various Midrashoth, there are some 30 full-program Midrashoth throughout the country, serving some 1,000 of the 8,000 graduates of religious high schools for girls (Ereli, 2018), with another approximately 2,500 in partial programs (Finkelstein, 2012). 
These are "Torah Lishmah" studies, intended to enrich the students' religious and spiritual world. They are usually accorded no academic recognition and provide no professional training. The study program in these settings is determined according to the worldview of each Madrasah and its rabbis and differs from place to place (Lotan \& Schwartz, 2006), since the national religious public has diverse views and different perceptions with regard to various ethical issues. Roughly speaking, one extreme may be said to have more conservative outlooks and another more open outlooks, with the majority of the populace somewhere in between. Hence, the Midrashot have well spread along this continuity between conservative and more open. The main topics that are under dispute and that are manifested more in the worldview of Zionist Midrashoth are the attitude to Israeli culture, the role of the rabbi, the attitude to mixed society and feminism, the integration between academia and Torah, etc. (Ne’emanei Torah Va'Avoda, 2018).

Studies at the Midrashoth are distinguished from studies at Yeshivot (Torah schools for men) both in the duration of studies and in their nature and content, particularly with regard to Talmud studies. The content of the studies includes a mix of basic topics: basic books, halakha (Jewish law), and faith. In addition, some of the Midrashoth also teach Talmud, Hassidism, studies of the inner soul, and Jewish thought. Each Madrasah determines the desired mix independently. The nature of the studies is comprised mainly of frontal classes, where the rest of the time is divided between "hevruta" type studies (in pairs or small groups) and self-study. In some Midrashoth, the nature of the studies takes the form of study sessions called "sedarim” (Ereli, 2018).

About half the full-program Midrashoth are headed by a male rabbi and the other half by a woman/female rabbi. The staff of the Madrasah is varied and comprised of male rabbis, female rabbis, and teachers, where some have more male figures and some more female (The Midrashot Website, 2019).

\section{The Midrasha as a Change Agent}

The "psychological moratorium", mentioned by Mead and Erikson (Muuss, 1988), occurs at the stage of searching for one's identity, in adolescence. This stage includes experiencing that involves the adolescent's identity, his or her relations with others and with ideals, all this without having to make any final commitment to define their identity in this way (Kashti \& Shalev, 1981).

Adolescents in the moratorium status are in the midst of the crisis stage and in a process of active search for alternatives. The process might be manifested in different academic experiencing, adventurism, or searching for fascinating experiences or continuous discussions on different life topics, in which individuals clarify their feelings and views. The "moratorium" status is considered a normative stage of transition for most adolescents on the way to consolidating their identity (Tzuriel, 1990).

In Israel, the moratorium continues after high school and military service, when young people go on a post-military trip. Some work after their discharge from the army in order to pay for the trip, and only then they continue to academic studies and marriage. In fact, many young people undergo a lengthier route in this way, taking time off for pleasure and to clarify their identity, and in fact relinquishing their duties during this period.

Among graduates of the state religious educational system, the moratorium takes a slightly different form. Male religious graduates of high schools and Yeshivot have a range of study settings: pre-military preparatory programs $^{1}$

1 Questionnaire for alumni of pre-military preparatory programs (ת). Hizun Institute. Retrieved from http://geobase.huji.ac.il/catalogdocs/f800/H_questionnaire1.pdf (in Hebrew). 
gathering momentum in recent years, in the transition from high school to academic studies in the moratorium, in addition to national/military service, and this is the Torah-oriented Madrasah for women (Finkelstein, 2012).

According to Ereli (2018), the Midrashoth were originally intended for the period after national service. However, there has been a rise in the number of pre-service Midrashoth as well, where students usually join the army subsequently. Side by side with providing students with a Torah-oriented education, many of the Midrashoth strive to produce graduates who will be active in Israeli society and among Diaspora Jewry and serve as leaders in their communities. But the Madrasah also has an important developmental role in the students' life, beyond its more formal purposes. The primary goal of the Midrashoth is to build a world view of Torah and faith and to reinforce one's self for themselves, as well as in order to start a family and for the Jewish people.

Nevertheless, according to Ereli (2018), Midrashoth with a full program are still the lot of the higher social stratum, serving more affluent families. Midrashoth with a combined program of studies and national service have been accumulating momentum in recent years and provide a response to women who are unable (for reasons of finances, time, or academic capabilities) or do not wish to study a full program.

\section{Women in Religious Zionist Society}

The "Kinyan Torah" (Acquisition of Torah) chapter, which is the last chapter in Tractate Pirkei Avot, deals with the virtues and benefits of Torah study and of occupation with Torah, but when reading, it becomes clear that the entire section is written in the male form. It is only the man who is instructed to engage in Torah study, and this occupation grants the man virtues, powers, and wonderful qualities listed by R. Meir. What about women who wish to study Torah? It appears that their fate is already sealed, as evident from the astute reply of R. Eliezer to the woman who dared present him with her own Torah interpretation, "There is no wisdom in a woman except with a spindle" (B. Yoma 66b), said R. Eliezer, and added elsewhere, "Whoever teaches his daughter Torah teaches her lasciviousness" (M. Sotah 84:4). Namely, women have no place studying Torah.

Nonetheless, over the generations, other voices were heard, for instance, Mishna Sotah Ben Azay says: “A person must teach his daughter Torah” (M. Sotah 84:4).

This question of the right and options of Jewish women for engaging in Torah has occupied the religious public sphere and figures of halakhic authority from time immemorial (Zohar, 2000). R. Kook, for instance, is of the opinion that women are naturally spiritually superior, so much so that the purpose of the precept of Torah study is to uplift men to the rank that women occupy naturally, with no need for study. Nevertheless, this was written some 60 years before the flourishing of the feminist movement and some 75 years before religious women dared ask the rabbis to join in studying. R. Kook admits that the current reality has changed. Namely, he believes that at present, girls too should be taught Torah, but we must not forget that this is a temporary and post factum state; and in the long term, we wish to return to women's natural spirituality (Shevet, 2004).

According to Tikochinsky (2010), there always Jewish women who studied Torah. Women such as Beruriah the tanaite, Rashi's daughters, the wife of the Maharal of Prague, and others. These women are the basis for our grasp of continuous female Torah study. In her opinion, the small extent of women who are yeshiva preparatory programs, Hesder yeshivas, and higher yeshivas. A new station has been added studying Torah at present might have a negative effect on the sense of continuity, and therefore, she sees the to the continuing tracks of female religious graduates of Ulpanot and religious high schools and it has been teaching of Torah to women in various settings as extremely significant. 
In recent years, teaching Torah to women has become a true phenomenon. The first buds appeared in the early 1990s, when the Lindenbaum (“Beruriah”), Matan, and Ein Hanatziv Midrashoth were opened. The unique feature of these Midrashoth, in contrast to the Michlalah in Bayit Vegan, for instance, was the clear focus on Talmud studies, which until then was considered forbidden for all women. Later, other Midrashoth and batei midrash for women were founded, such as the Madrasah in Migdal Oz, Nishmat, and the beit midrash of Beit Morasha. Each beit midrash had its own uniqueness and slightly different goals. Today, it may be said that a growing number of girls who complete their high school studies and national service find themselves in one setting or another of Torah study for a year or two before "entering the big wide world" (Tikochinsky, 2010, p. 8).

According to Ereli (2018), the emphasis on contents related to women's status depends to a great degree on the ideology of the school head and staff. More liberal Midrashoth will put more of an emphasis on women's status and feminism in halakha, as well as on more feminist-oriented activities, such as celebrating festivals through women's megillah readings. In contrast, more conservative Midrashoth will choose other foci.

\section{Torah Study Over Time}

Hence, in recent years, Torah study for women has become a distinct mark of the religious women's progress. Nonetheless, the advancement of women in this area is overshadowed by the prevalent conservative line of reasoning. However, Torah study for women is on the rise and is facilitating spiritual growth for women as well, not only as serving their husbands, the Torah scholars, rather also as worshippers of God in their own right. Therefore, exploring the attitude of Orthodox women to Torah study may reflect feminist developments, even if not defined as such (Ereli, 2018).

According to Ereli (2018), it appears that no significant change has occurred in the contents taught at the Midrashoth in the last two decades. Namely, Midrashoth that stressed Talmud study 20 years ago are continuing to do so today as well. Nevertheless, currently there seem to be developments on the social dimension, with an emphasis on trips, weekends, and volunteer work. So, this year of studies has a meaningful part in creating experiences and building one's personality beyond the academic impact.

There also seems to have been no development in the nature of the studies. Most studies at the Midrashoth take the form of frontal teaching, unlike men who study in the form of sedarim, although the initial purpose of the Midrashoth when established was Anglo-Saxon studies that are closer to the men's study format. According to Ereli (2018), one of the contemporary goals of the Midrashoth is Talmud study, because women too can study Torah, rather than resembling men's way of studying.

According to the literature, this goal appears to have been preserved over the years. The desire to study Talmud in the same format as men was the primary motivation for opening the Midrashoth in the 1990s, when they were oriented at "Torah Lishmah" and Talmud studies like the men, from more feminist motives (Tikochinsky, 2010). According to Ereli (2018), this motivation exists today as well, but it is joining a range of other more conspicuous motivations, such as consolidating one's personal and spiritual identity, which are more compatible with the postmodern approach.

The primary goal of the Midrashoth today is to construct a world of Torah and ideology, to build up the students' Torah-oriented backbone for their own sake. The present-day postmodern approach is characterized by an emphasis on inner work, self-consciousness, and building one's self, rather than becoming familiar with the Maharal or R. Kook, for instance. This movement is influenced by the new generation that focuses on 
searching for and forming their identity, searching for meaning and awareness, as well as from the students themselves who wish to become familiar with their self (Ereli, 2018). According to Ereli (2018), the main motives for studying at a Midrasha at present are the desire to continue studying and to enhance their faith and soul. Sometimes, the Madrasah becomes a corrective experience for an unsuccessful experience in high school or (military or national) service, sometimes as a therapeutic place, and sometimes, the motive is to seek an answer to existential questions.

Today, there is greater legitimization for women to study in a Midrasha, but it is still less obvious and less organized than for men.

The scarcity of literary sources stems from the little research on the Midrashoth, and therefore, our study is a breakthrough study in this field and adds to the existing research. We expect to find an association between the growth process of the Torah-oriented Midrashoth and enhancement of women's status within religious Zionist society. Moreover, an association will be found between the motivation of Midrasha students to study there and current-day postmodern processes.

\section{Method}

\section{Participants}

The original sample was intended to comprise 120 Jewish women, graduates of full-program Midrashoth in the last five years. Ultimately, due to the high response rate, 225 participants were included. Nevertheless, the statistical analyses were eventually conducted with 217 women, as eight were excluded due to incompatibility with the research criteria, as explained below.

Of all respondents, 220 had participated in a full program, three in a partial program, and two in a combined program with national service. Since the study focuses on women who studied a full program, observations of the partial program and the combined program were removed from the statistical analyses. The duration of the respondents' studies in the Torah-oriented Midrashoth ranged from six months to two years. Four respondents studied at a Midrasha for six months, 198 for one year, and 23 for two years. Since the focus in the current study was on a full program lasting at least nine months, respondents who had studied for six months were excluded.

In sum, the statistical analyses were conducted on 217 respondents who had participated in a full program for at least one year. The age range of the respondents was 19-27 years old. The mean age was 22.6 years old. Of all respondents, 143 were single, 67 married, one divorced, and six with other marital status. In addition, 71 were living in small towns, 134 in cities, four on a kibbutz, three in a Torah-oriented group within a city (“Garin Torani”), four on a moshav, and one elsewhere.

\section{Tools}

Questionnaire on perceptions of women's status. The current study measured women's status in religious Zionist society by means of a questionnaire on women's status. This scale was developed by Kehat (1999) and includes seven questions examining whether and to what degree women in Jewish Orthodox society are occupied with feminist dilemmas. The first question related to the respondent's spiritual development, i.e., Torah study ("What do you think about Torah studies for women today?"). The second question examined the attitude of these women to the group leading the change, women who study one or two years at a yeshiva for women ("What is your attitude to women who study 'Torah Lishmah'? Do you think that they are a desirable 
role model?”). Questions four and five, for example, examine the sociological point of view of these women regarding developments within Orthodox society, how they see the influence of the Midrashoth and the changes in women's status within their society ("Do you think that the full-time Midrashoth for women affect the life of religious women today?”, "What do you think about the status of religious women today?”).

Respondents completing the questionnaire were asked to state their attitude to the question (very positive, indifferent, and very negative).

Questionnaire on motivation to study at a Midrasha. In the current study, respondents' motivation to study at a Midrasha was measured by an opinion questionnaire of the Mattat Website ${ }^{2}$. The website includes opinions of over 1,000 graduates of national service and Midrashoth and lets high school graduates use these to reach decisions regarding their future year of national service or Midrasha. The respondents were requested to complete this questionnaire, which includes 24 open- and closed- ended questions. Closed-ended questions, such as demographic questions (for instance, type of residential town, age, and others) were aimed at understanding the respondents' background. Questions related to life at the Midrasha and special features included, for instance, Torah study, Talmud study, volunteer work, preparation for military service, social activities, other extracurricular activities, and local host families. Respondents completing the questionnaire were asked to report to what degree each feature was present at their Midrasha (not at all, slightly, and very much) in addition to open questions on their experience of the Midrasha (for instance, "Did your studies at the Midrasha affect your life and the decisions you made? If so, in what way?”).

Questionnaire for graduates of pre-military settings. This scale was originally developed by the Hizun Institute for alumni of pre-military settings (with the support of the Avi Chai Foundation), and in our study, we chose to use some of these questions for graduates of women's Midrashoth as well. Some of the questions involved the impact of the Midrasha in various areas (for instance, "What impact did the Midrasha have on your motivation to study Jewish sources and texts?", "What impact did the Midrasha have on your process of forming worldviews?”, and so on). In addition, the respondents were asked how they define themselves as situated along the continuity of Jewish identity and how their parents would define themselves on this continuity.

\section{Research Procedure}

After receiving ethical approval, a link to the questionnaire was distributed on social networks (for instance, Facebook) to be completed voluntarily (with no compensation). Respondents were recruited through a snowball sampling method. Anonymity was assured. People interested in responding were referred to an online questionnaire that began with a page of general information on the study and instructions, followed by the details of the questionnaire. Replies to the questionnaire were entered in the system and sent to the researchers for further data collection and statistical analyses. In addition, an interview was held with Dr. Yael Ereli, chairperson of the Forum of Torah-Oriented Midrashoth for Girls. After the data collection, eight women were found to be incompatible with the research criteria and were therefore excluded from the study. This left 217 respondents on which appropriate statistical analyses were conducted.

\footnotetext{
${ }^{2}$ Opinion questionnaire for Midrasha graduates, the Mattat Website, http://mattat.org.il/ci/index/php/fill/mobile_army_fill (in Hebrew).
} 


\section{Findings}

Of all the respondents, one defined herself as secular, one as traditional, 205 as religious, four as ultra-Orthodox, and six as others. In contrast, when asked how their parents would define themselves on the continuity of Jewish identity, three said secular, nine traditional, 194 religious, one ultra-Orthodox, and 10 others. Of all respondents, 137 had studied at an Ulpana in high school, 46 in an Ulpanit, five in a mixed-gender public high school, 26 in a public high school for girls, and only three in a secular public high school.

While studying at the Midrasha, five had lived at home, 24 in a rental apartment, and 188 had dormitories at the Midrasha. Most of the respondents had spent weekends at the Midrasha $(N=215,99.1 \%)$, and only two did not spend weekends at the Midrasha (0.9\%).

The nature of studies at the Midrasha is diverse and ranges from "hevruta" studies $(N=184)$, frontal classes $(N=220)$, self-study $(N=157)$, and sedarim $(N=10)$, namely, there is a combination of different study styles at the Midrashoth, with a low prevalence of sedarim relative to other forms of study (see Figure 1).

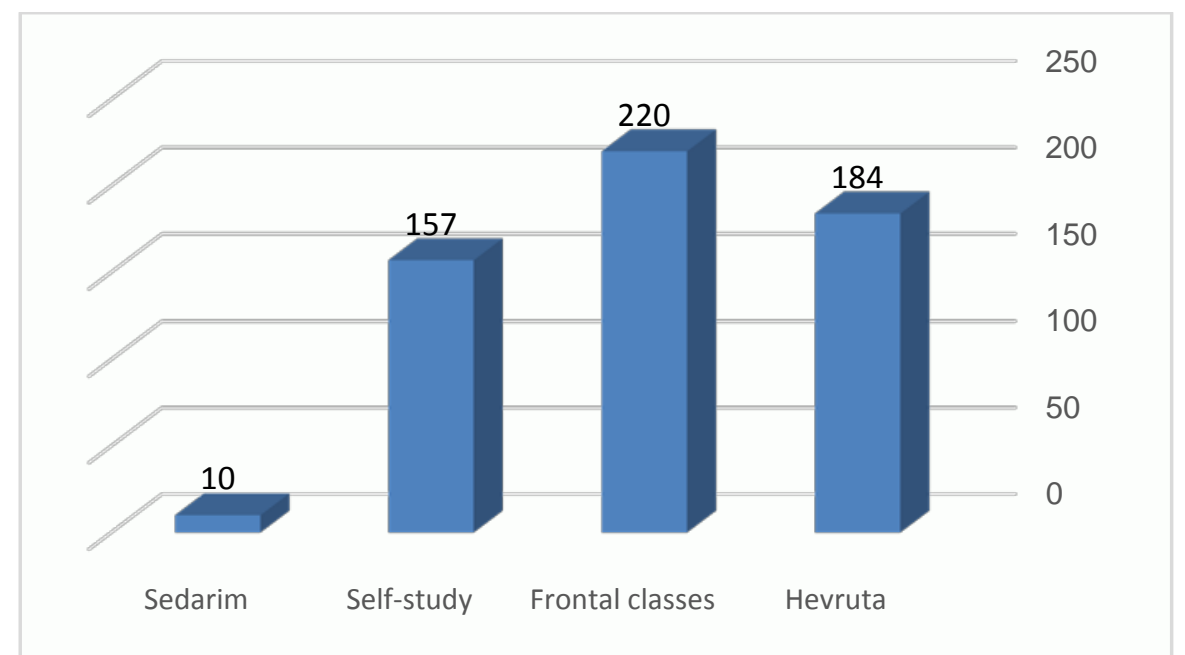

Figure 1. Frequency distribution for the nature of studies at the Midrasha (Respondents could choose more than one answer).

It seems that the studies themselves were diverse also with regard to the contents and the added value at the Midrashoth. Respondents were asked to what degree certain contents were emphasized on a scale of 1-3, with 1 being not at all and 3 very much. It seems that relatively more emphasis was given to studies of faith ( $M$ $=2.77, S D=0.48)$, Jewish thought studies $(M=2.7, S D=0.48)$, social activities $(M=2.53, S D=0.67)$, studies of Hassidism $(M=2.49, S D=0.48)$, halakha studies $(M=2.5, S D=0.54)$, and bible studies $(M=2.48, S D=$ $0.53)$, and less to Talmud studies $(M=1.88, S D=0.8)$ and contents related to added value, such as preparation for military/national service $(M=1.7, S D=0.82)$, local host families $(M=1.47, S D=0.71)$, and volunteer work $(M=1.4, S D=0.56)$ (see Figure 2). 


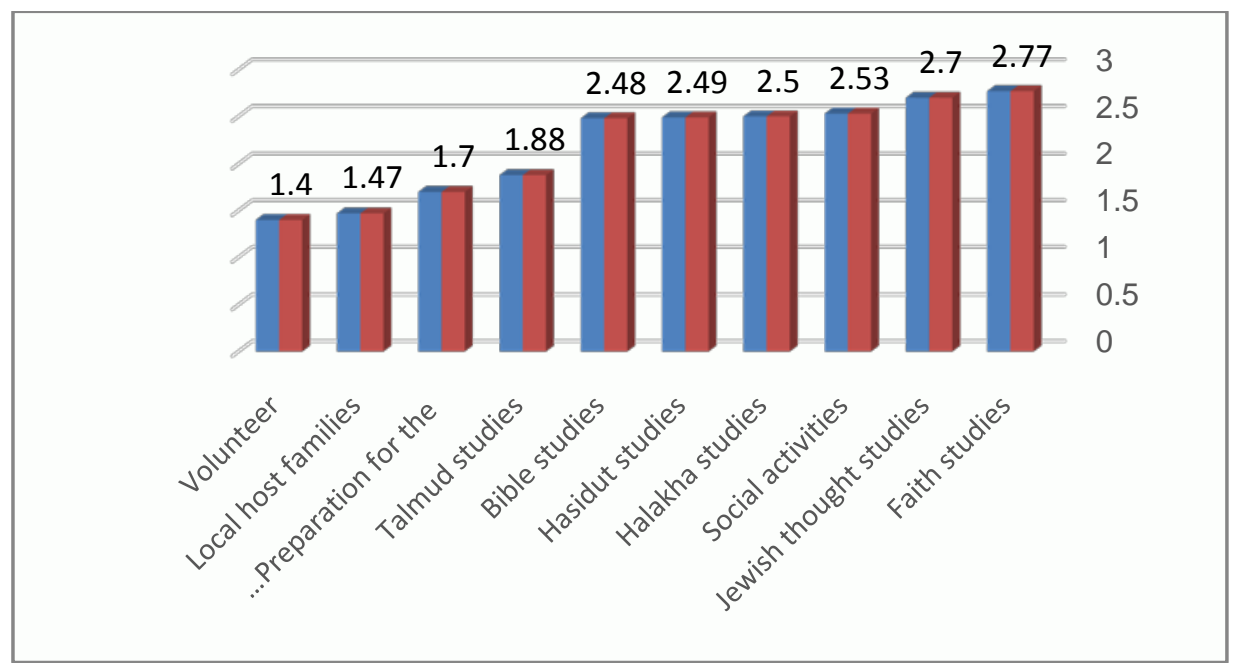

Figure 2. Frequency distribution for questions surveying the emphasis given to various contents at the Midrasha.

Of all respondents, 89 studied at the Midrasha before their (national or military) service and 125 after the service, while three studied during their service (see Figure 3).

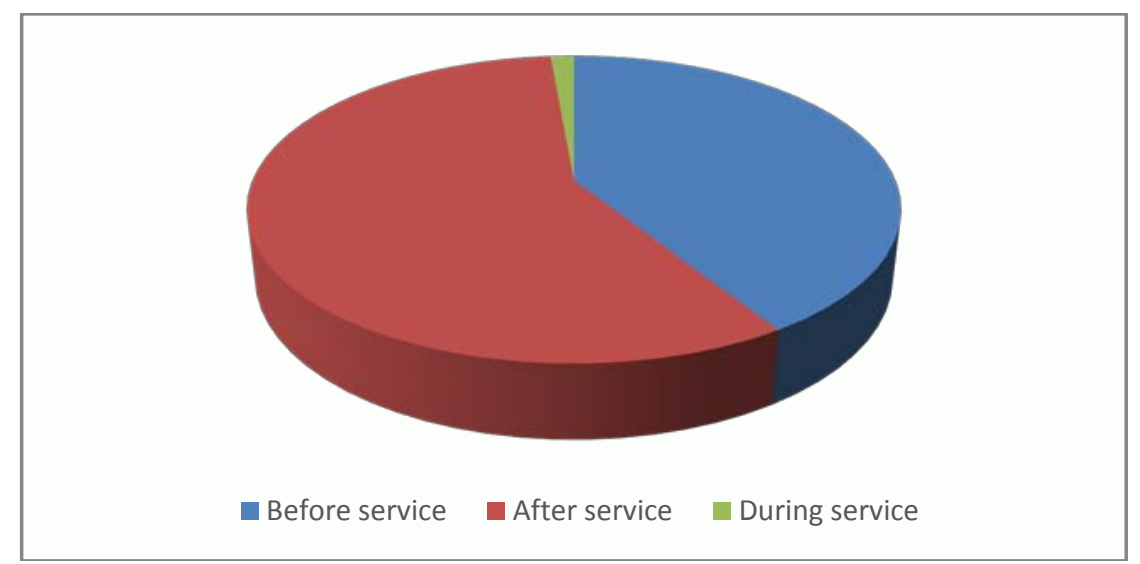

Figure 3. Frequency distribution for the question of at which stage of life did they choose to study at the Midrasha.

Subsequently, 83 of the respondents continued to national or military service (50 to national service, 23 to military service in an organized group- “Garin”, three to military service in a program for Torah-oriented culture, and six to another setting). In addition, 104 continued to academic studies, 24 entered the labor market, and seven answered that they decided to do something else after completing their studies at the Midrasha (most said that they chose to travel).

It seems that motives for studying at the Midrasha were very diverse, and most respondents had more than one reason for choosing to do so. The leading motives for studying at the Midrasha were to build one's world view $(N=146)$, to clarify one's personal identity $(N=143)$, to study “Torah Lishmah” $(N=133)$, and to clarify one's religious identity $(N=126)$. Moreover, reasons such as preparation for life, a career, and so on $(N=108)$, as well as for religious enhancement $(N=101)$ were also common. Less common motives were searching for meaning $(N=79)$, seeking answers for existential questions $(N=70)$, to become familiar with Jewish texts and sources $(N=61)$, a corrective experience following high school/ national service/ military service $(N=37)$, and as a gap year $(N=22)$ (see Figure 4$)$. 


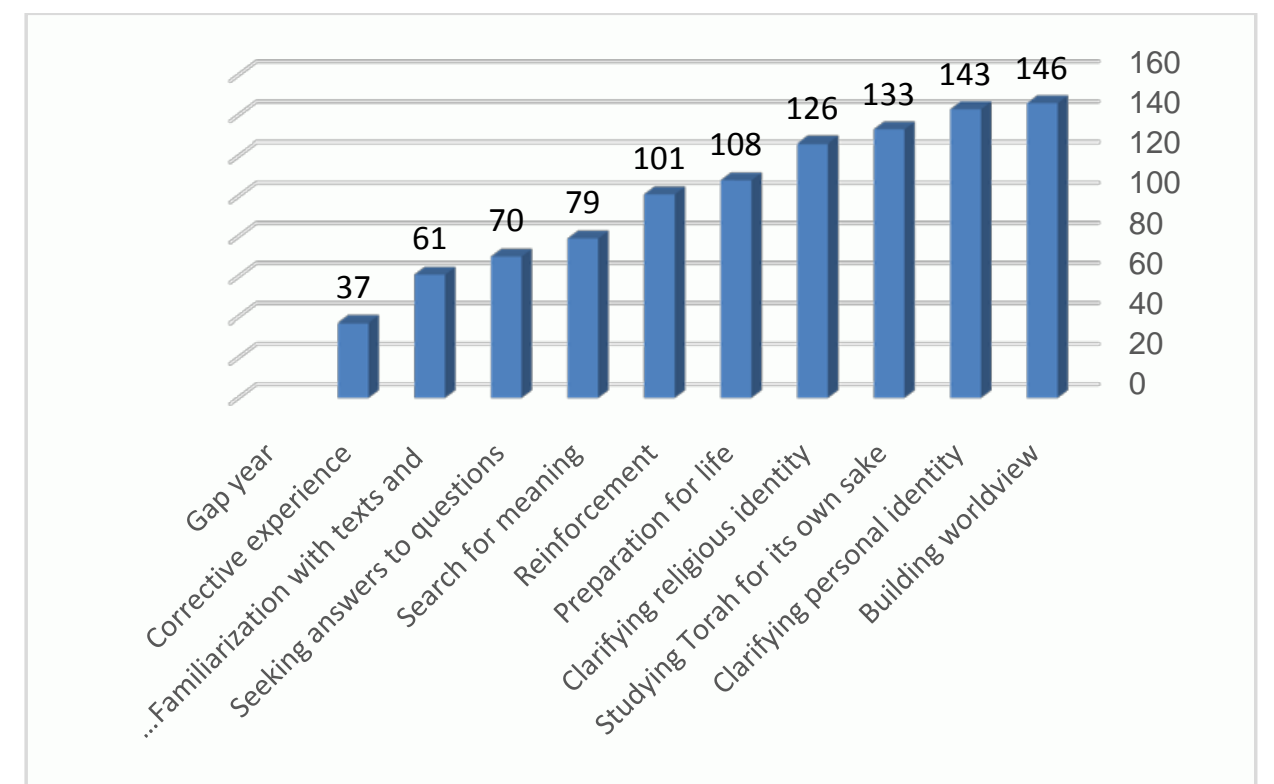

Figure 4. Frequency distribution for respondents' motives for studying at the Midrasha (Respondents could choose more than one motive).

It seems that the Midrasha experience was meaningful for the respondents. When asked whether they mention their studies at the Midrasha in their CV or on dates most said that they normally do $(N=169,79 \%)$, 42 respondents said sometimes, if relevant (19.4\%), and only two said that usually not (0.9\%). Satisfaction was measured on a scale of $1-5$ and found to be very high among the respondents $(M=4.4, S D=0.66)$. In addition, the respondents were asked how they summarize their time at the Midrasha on a scale of 1-5, and here too very high satisfaction was found $(M=4.63, S D=0.58)$.

When asked, in retrospect to what degree did the Midrasha impact you in various areas, the greatest impact found was on forming one's world view, motivation to study and become familiar with Jewish texts, and familiarity with Jewish texts and sources. The lowest impact of the Midrasha was on motivation to engage in social and community activities. The data are presented in Table 1.

Table 1

Questionnaire on the Impact of Midrasha Studies in Various Areas

\begin{tabular}{|c|c|c|c|c|c|c|c|c|}
\hline & & $\begin{array}{l}\text { Motivation to } \\
\text { study and } \\
\text { become } \\
\text { familiar with } \\
\text { Jewish texts } \\
\text { and sources }\end{array}$ & $\begin{array}{l}\text { Motivation to } \\
\text { engage in } \\
\text { social and } \\
\text { community } \\
\text { activities }\end{array}$ & $\begin{array}{l}\text { Forming } \\
\text { one’s } \\
\text { world } \\
\text { view }\end{array}$ & $\begin{array}{l}\text { Becoming } \\
\text { familiar with } \\
\text { Jewish texts } \\
\text { and sources }\end{array}$ & $\begin{array}{l}\text { Becoming } \\
\text { familiar with } \\
\text { different } \\
\text { approaches to } \\
\text { the Jewish } \\
\text { tradition and } \\
\text { culture }\end{array}$ & $\begin{array}{l}\text { Ability to } \\
\text { develop social } \\
\text { ties and to } \\
\text { become } \\
\text { integrated in the } \\
\text { community }\end{array}$ & $\begin{array}{l}\text { Finding a shared } \\
\text { language and } \\
\text { ability to } \\
\text { collaborate with } \\
\text { people who come } \\
\text { from a different } \\
\text { background than } \\
\text { me }\end{array}$ \\
\hline \multirow{2}{*}{$\mathrm{N}$} & Valid & 215 & 214 & 215 & 213 & 214 & 214 & 215 \\
\hline & Missing & 2 & 3 & 2 & 4 & 3 & 3 & 3 \\
\hline \multicolumn{2}{|c|}{ Mean } & 5.4 & 4.14 & 5.44 & 5.34 & 4.93 & 4.36 & 4.6 \\
\hline \multicolumn{2}{|c|}{ Std. deviation } & 0.86 & 1.33 & 0.73 & 0.78 & 0.91 & 1.19 & 1.2 \\
\hline
\end{tabular}

Note. Each statement begins with: "In retrospect, to what degree did the Midrasha impact you in...”.

In order to examine the correlations between the variables of satisfaction with studies, realizing one's abilities, summary of one's study experience, and impact on motivation and various life areas (which includes 
seven items), a series of Pearson correlations was calculated.

A significant strong positive correlation was found between satisfaction and summary of time at the Midrasha: $r=0.52, p<0.001$, such that the higher the satisfaction the more the time at the Midrasha was described as good. Nevertheless, all the correlations examined between satisfaction with studies and the impact of the Midrasha on motivation and various life areas were found to be insignificant. These findings were also repeated in the correlations examined between summary of study experience and motivation and various life areas, which were also found to be insignificant.

No correlation was found between the impact of studies at the Midrasha and satisfaction or summary of the Midrasha experience, rather only with realization of the respondents' abilities.

A significant medium positive correlation was found between realization of abilities and the general impact of studies $(r=0.39, p<0.001)$ and particularly between realization of abilities and impact on motivation to study and to become familiar with Jewish texts and sources ( $r=0.35, p<0.001$ ), between realization of abilities and impact on the ability to develop social ties and to become integrated in the community ( $r=0.31, p<0.001$ ), and between realization of abilities and impact on motivation to engage in social and community activities $(r=0.23, p<0.001)$.

Significant weak positive correlations were found between realization of abilities and the impact of the Midrasha on becoming familiar with Jewish texts and sources $(r=0.23, p<0.01)$, between realization of abilities and impact on forming a world view $(r=0.20, p=0.001)$, between realization of abilities and impact on finding a shared language and ability to collaborate with people from a different background than me $(r=$ $0.19, p<0.01$ ), between realization and becoming familiar with different approaches to the Jewish tradition and culture ( $r=0.22, p<0.01$ ), between realization and finding a shared language and ability to collaborate with people from a different background than me $(r=0.19, p<0.01)$.

In order to examine the hypothesis whereby an association would be found between women's status and the growth process of the Midrashoth we conducted several analyses.

In addition, we conducted a series of Pearson correlations between women's status, special features of the Midrasha, and the impact on various topics. Weak positive significant correlations were found between women's status and motivation to learn and become familiar with new texts ( $r=0.22, p<0.01)$, between women's status and actual familiarization with Jewish texts and sources $(r=0.23, p<0.01)$, and between women's status and Talmud studies $(r=0.19, p<0.01)$. The other correlations with women's status were not found to be significant.

We investigated how women's status was perceived (on a scale of 1-3) by the respondents, and found very positive opinions $(M=2.78, S D=0.2)$. When asked for their opinion on Torah study for women, $96.3 \%$ of the women were found to perceive this very positively. Nevertheless, when asked about their attitude to women who study "Torah Lishmah" and whether they are perceived as desirable role models, 84\% perceived this very positively and $16 \%$ said that they are indifferent. When asked about their attitude to Talmud study by women, only $49 \%$ of the respondents perceived this very positively, $42 \%$ were indifferent, and $9 \%$ perceived it very negatively.

When asked how they see their future as religious women, here too the opinions were sweepingly positive, as expressed by $95 \%$ of the respondents. But when asked how they see the future of religious women in religious matters, there was a drop in the scores, with $80 \%$ responding that they see it very positively and $17 \%$ being indifferent. When asked about the present the picture was glummer, with only $65 \%$ of the women 
perceiving women's current status as very positive, 30\% being indifferent, and 5\% perceiving women's current status as very negative. Nonetheless, when asked about the impact of the Midrashoth on the life of religious women at present, $97.2 \%$ answered that there is a very positive impact.

Then, the frequencies and means of the women's status questionnaire were calculated as completed by Midrasha students in a study conducted two decades ago, compared to the data in the current study (see Figure 5). An increase was found in all aspects, where present perceptions were more positive than past perceptions, aside from two items-perceptions of women's Talmud studies and of the status of religious women today, where there was a drop compared to the past. Namely, today these are perceived less positively than in the past.

A very significant increase of $35 \%$ was observed in replies to the question: "Do you think that the full-program Midrashot for women have an effect on the life of religious women today?”

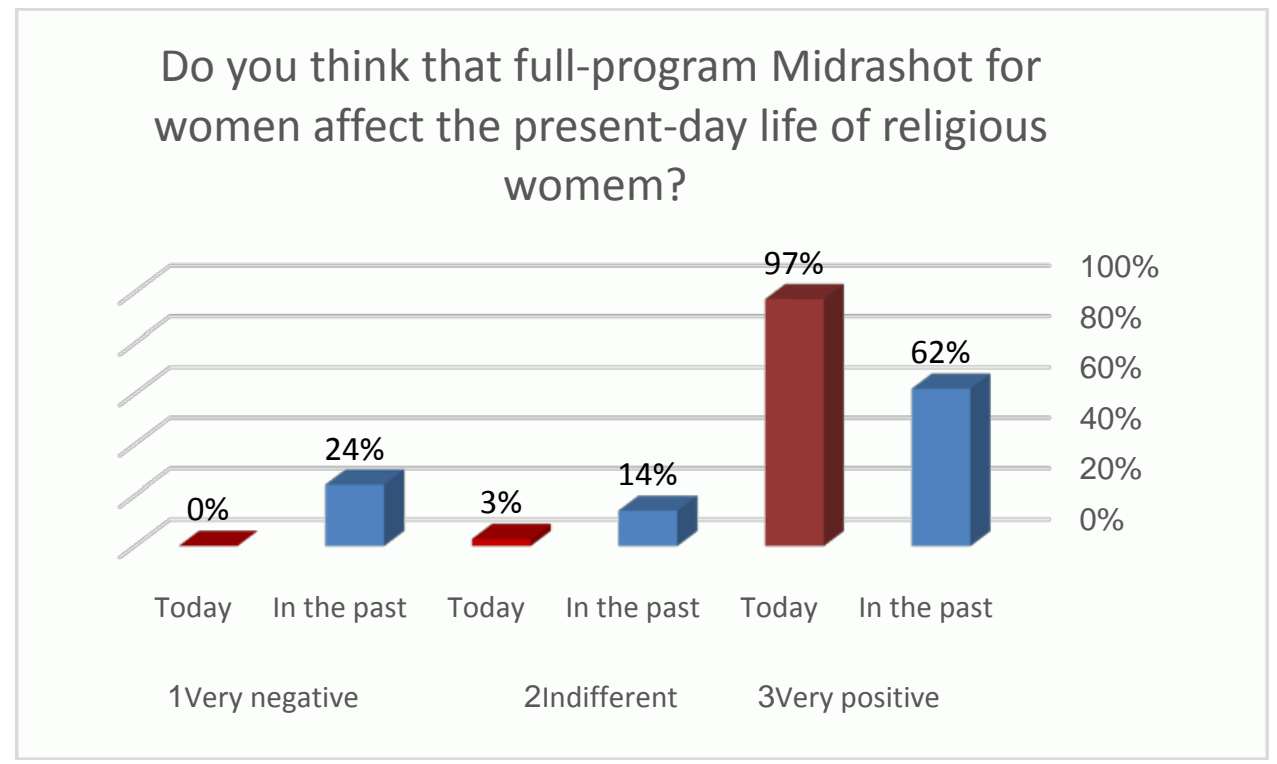

Figure 5. Questionnaire on women's status (comparison of mean scores from administration in the past and in the current study).

In order to examine whether there is a significant difference in women's status in the past and present, a $t$-test for independent samples was held. A significant difference was found between the two groups $(\mathrm{t}(275)=$ $2.61, p<0.01)$. It seems that the perception of women's status is higher today $(M=2.78, S D=0.1)$ than in the past $(M=2.55, S D=0.17)$.

\section{Conclusion and Discussion}

This study examined the association between the growth process of Torah-oriented Midrashoth and enhancement of women's status in religious Zionist society. In addition, the association between the motives of Midrasha students for studying there and postmodern processes occurring at present was also examined. In our study, we found little research on the subject, therefore aside from the few sources in the literature we tried to overcome this in the following ways: a very large sample of respondents $(N=217)$, quantitative research combined with qualitative research (open questions), and an interview conducted with Mrs. Yael Ereli, Chairperson of the Forum of Torah-Oriented Midrashoth for Girls. 
This study included only women who had taken a full program in the past five years. Many aspects of the Midrasha experience were examined, beginning from the contents taught at the Midrasha, motives for studying at the Midrasha, the impact of the Midrasha on various areas, their perception of women's status, and others. This is in order to receive a full and more complex picture of the current state of affairs at the Midrashoth.

With regard to the association between the growth process of the Torah-oriented Midrashoth and enhancement of women's status, it appears that there is a high prevalence of women who come before their national/military service. In the past, the Midrashoth were intended for women after service, while our study found that nearly half the women had taken a full program before their service. The phenomenon of women who come to the Midrasha immediately after high school is growing (Ereli, 2018).

When examining the association between the mean score on the women's status questionnaire and the various study contents, the only significant correlations found were with motivation and actual study of Jewish texts and sources, as well as Talmud studies. The higher the score on the women's status questionnaire is, the higher the study and motivation to study Torah and Talmud is. Surprisingly, this was not always compatible with the respondents' original views. Although almost all the women perceived Torah study for its own sake as very positive, the percentages of support dwindled when asked whether women who study "Torah Lishmah" are a positive role model, and dropped significantly when asked about women who study Talmud. Namely, it seems that although the initial goal of establishing the Midrashoth in the 1990s was to teach Talmud to women, there is still no wide consensus about this among religious women.

Furthermore, optimism was found regarding the future, where almost all the women perceived their future as religious women very positively, but when asked about the status of women today the situation was significantly less positive. Namely, there is a discrepancy between the current state of affairs and the perceived future regarding women's status. It seems that the role of the Midrasha regarding this discrepancy is significant and very important, affecting women's status today and in the future. Almost all the respondents agreed that the Midrashoth have a very positive effect on the life of religious women today. Indeed, satisfaction with the Midrashoth was very high (4.63) and the respondents summarized their Midrasha experience as excellent. From the responses: "Torah as s shaper of life”, “One year that has an impact on an entire life”, "Productive, shaping consciousness, challenging", and "Meaningful and even life changing”. This is not surprising, considering that the Midrashoth are a place to which women come willingly and voluntarily, and they appear to experience a significant and important process that remains with them for the rest of their life.

In addition, we compared these perceptions to those in the past (Kehat, 1999-Appendix 1) and found a significant increase in all aspects aside from women's perception of Talmud studies, where there was a drop of 11 percent compared to the past, and the status of religious women today, where there was a drop of $13 \%$ compared to the past. In addition, the perception of women's current status was found to be significantly higher than the perception of women's status in the past. In order to examine the place of the Midrasha in this, it is possible to refer to the question of whether full-program Midrashoth for women have an effect on the life of religious women at present, where there was a considerable increase of $35 \%$ relative to the past. It appears that the Midrashoth not only fulfill an important role in the life of the students but rather also impact the life of religious women and thus serve as change agents in the role of women in religious Zionist society.

Postmodern processes indeed appear to be associated with the motives of Midrasha students. The major motives for choosing to study at a Midrasha were found to be constructing a world view, clarifying one's personal identity, studying “Torah Lishmah”, and clarifying one’s religious identity. Moreover, reasons such as 
preparing for life, a career, etc., as well as religious enhancement, were also common. Less common motives were searching for meaning, seeking answers to existential questions, becoming familiar with Jewish texts and sources, a corrective experience after high school/national service/military service, and as a gap year.

Namely, the wish to construct their world view both personally and religiously is the main motive that led the respondents to study at a Midrasha. The respondents described "lots of introspection", "time for myself", "confidence in my self-worth”, “connecting to Torah from a deep place”, and "I found myself”. The greatest impact of the Midrasha was indeed found to be its impact on forming one's world view, but also on motivation to learn and becoming familiar with Jewish texts as well as familiarization with Jewish texts and sources. Interestingly, although constructing their world view was a major motivation, familiarization with Jewish texts and sources was a relatively minor motivation and it only appeared among about one third of the respondents. In practice, the Midrasha had an impact not only on learning this type of texts but also on the motivation to learn these texts. The respondents described, in the question on the most significant thing they had received from the Midrasha: "ability to be myself and attentive to myself”, "introspection”, "understanding what course of life I would like to follow", "the ability to love myself", "confidence in my self-worth", and "I found myself”. The significant processes undergone by the respondents appear to be related to inner work and seeking one's self, which are compatible with the postmodern conception (Ereli, 2018; Tikochinsky, 2010).

The wish to resemble men seems to be a less significant element in choosing studies in the Midrashoth, as evident by the fact that studying Torah and Talmud are not the main reasons for studying. In addition, it seems that although the customary form of study among men is that of sedarim, among women this is not true and only 10 answered that studies also take the form of sedarim (Ereli, 2018; Tikochinsky, 2010). The most common form of studying at present in the Midrashoth is frontal classes, hevruta style studies, and self-study. The current study did not check how women perceive these forms of study, whether they would prefer to learn in the form of sedarim or as they study today. In any case, it seems that there is a lack of similarity in certain aspects between women and men, but the respondents' satisfaction with the Midrasha and how they summarize their experience remain very high and are not negatively affected.

Another interesting fact is that nearly half the women $(N=90)$ came to study at the Midrasha before their national/military service. This phenomenon is on the rise, and at present, more Midrashoth have special programs for high school graduates that prepare them for military or national service. Today, the phenomenon of high school graduates who come to Midrashoth is gradually increasing (Ereli, 2018), and this is evident in the current study. In addition, the study found a positive correlation between the impact of the Midrasha on the respondents' life and realization of their abilities, where realization of abilities was found associated in particular with motivation and actual learning of Jewish texts, the ability to develop social ties, and a shared language with different people, as well as motivation to engage in social and community activities and constructing one's world view. It appears that the Midrasha has a role in constructing students' world view, but also in their integration in society and in the community, compatible with the current literature (Ereli, 2018).

In sum, it seems that the Torah-oriented Midrashoth for women are constantly on the rise and fulfill an important part in women's development, with Midrasha studies coming before or after service, at the moratorium stage of religious women, helping to develop their personal and religious world view. At the same time, the Midrashoth fulfill an important role in enhancing the status of religious women, legitimizing the construction of women's personal and spiritual identity, as well as increasing the legitimacy of learning "Torah Lishmah" by women. The motives for learning appear to be compatible with the postmodern processes that 
religious women are undergoing, where the current emphasis is on spiritual and personal growth. While in the past, the emphasis was on Torah study for its own sake and on Talmud, as well as resembling men in this area, transferring the focus from a feminist approach of "women can study Torah too" to focusing on one's self and inner life may be more emblematic of enhancing women's status at present and the hope for enhancing their status in the future.

\section{References}

Ereli, Y. (2018). Interview with chairperson of the Forum of Torah-Oriented Midrashoth for Girls. Telephone interview. (in Hebrew).

Finkelstein, A. (2012). The state religious educational system: State of affairs, trends, and achievements. Report by Ne'emanei Torah Va'Avodah. (in Hebrew)

Kashti, Y., \& Shalev, U. (1981). Collective residential schools as socializing organizations: The case of the "educational institution” of Hashomer Hatzair. Studies in Education, 23-40. (in Hebrew)

Lotan, O., \& Schwartz, E. (2006). Torah-oriented Midrashoth for girls. Knesset Report, Information and Research Department. Retrieved http:/fs.knesset.gov.il/globaldocs/MMM/2a189eff-9432-e811-80de-00155d0a0235/2_2a189eff-9432-e811-80de-00155d0a0 235_11_7268.pdf (in Hebrew)

Muuss, R. E. (1988). Theories of adolescence. New York: Crown Publishing Group/Random House.

Ne'emanei Torah Va'Avodah (2018). New auxiliary map for the generalized mapping of midrashot for high school graduates. Retrieved -94\%7D\%9A\%7D\%93\%7D\%97\%7D\%-8A\%7D\%96\%7D\%2A\%7D\%-AA\%7D\%4A\%7D\%E9\%7D\%/li.gro.adovarot//:sptth D\%9A\%7D\%-C9\%7D\%99\%7D\%C9\%7D\%B9\%7D\%E9\%7D\%-99\%7D\%95\%7D\%4A\%7D\%99\%7D\%E9\%7D\%C9\%7D\% /95\%7D\%91\%7D\%2A\%7D\%-AA\%7D\%95\%7D\%9A\%7D\%8A\%7D\%93\%7D\%E9\%7D\%-C9\%7(in Hebrew)

Shvat, A. (2004). Women's soul and education in our generation (Study of the teachings of the Re'aya based on new sources in his writings). Tzohar, 18, 119-128. (in Hebrew)

The Midrashot Website. (2019). Retrieved June 22, 2019, from /https://midrashot.co.il/type/full (in Hebrew)

Tikochinsky, M. (2010). And his sister stationed herself at a distance: The revolution of Torah study for women - the second generation. De'ot, 50, 19-22. (in Hebrew)

Tzuriel, D. (1990). Ego identity versus identity diffusion: Developmental and educational perspectives. Megamot, 32, 484-509. (in Hebrew)

Zohar, Z. (2000). The attitude of Rabbi Yosef Masas towards women's Torah study. Pe'amim, 82, 50-162. (in Hebrew) 